\title{
Diary Keeping in Writing Education
}

\author{
Betul Keray Dincel ${ }^{1}$, Hilmi Savur ${ }^{2}$ \\ ${ }^{1}$ Faculty of Education, Aksaray University, Aksaray, Turkey \\ ${ }^{2}$ Faculty of Education, Aksaray University, Aksaray, Turkey \\ Correspondence: Betul Keray Dincel, Faculty of Education, Aksaray University, Aksaray, Turkey.
}

Received: November 12, 2018

Accepted: November 28, 2018 Online Published: December 6, 2018

doi:10.11114/jets.v7i1.3758

URL: https://doi.org/10.11114/jets.v7i1.3758

\begin{abstract}
One of the many types of texts that can be used in writing education is the diary. In this study, the opinions of the Turkish language teacher candidates about diary keeping and their diaries kept for two months in which they could freely express their thoughts were analyzed. It is a qualitative study in which thirty-four participants' diaries were examined, and semi-structured interviews were conducted with seventeen randomly selected candidates. It is observed that the topics dealt by the teacher candidates in their diaries mainly focused on themes such as education-teaching activities, life, feelings, thoughts, relatives, nature, important days, diary, problems, personal development, and writing skills. The emerging codes from these interviews were grouped as: Diary, problems, personal development, and writing skills. The results of this research reveal that candidates who regularly keep a diary begin to question their lives and try to manage them better. Moreover, it was shown that diary keeping, which is regular writing, has an important role in the development of writing ability.
\end{abstract}

Keywords: diary keeping, writing, skill, education

\section{Introduction}

Writing is a skill in which the students begin to acquire from the first year of the primary school education. Writing is a tool through which we can express feelings and thoughts by writing them on a paper or electronically. The importance of writing is emphasized by the following proverb "The words will fly away, the written word will remain."

Like all the other kinds of skills, writing skills are gained by applying it. In order not to lose innate abilities one has to work on and develop them. If one can strongly express emotions and thoughts, he or she should not be afraid to put them in written words. On the contrary, one must transmit them to the others with pleasure and enthusiasm and make them eternal (Yildı, Okur, Arı, Yılmaz, 2008: 204).

According to Bangert-Drowns and colleagues, since the early 1970s, many educators have been using writing as a way of improving learning. For this reason, they have claimed that writing got closer to human speech and supports learning strategies and is a form of learning (Bangert-Drowns, Hurley, Wilkinson, 2004).

There are many types of texts that can be used in writing education. One of these text types is a diary. Y1ldiz and his colleagues stated that the pleasure of writing should be illustrated among students by promoting different activities such as keeping diaries, making memo books, writing letters to different people from different places once a week and writing reports on the events taking place during their classes (Yıldı, Okur, Ar1, Yılmaz, 2008).

In the literature "journal, diary, log" words (Alterman, 1965; Hiemstra, 2001) are being used for the concept of "diary." Keeping a diary is a tool for recording personal thoughts, everyday experiences and developing insights. In the process, the person usually talks to himself, to another person, or even to someone imaginary. According to Willard (1972), the term "diary" derives from the Latin word "diarium." It means the daily wage paid for a legionary in the Roman army. According to Willard these diaries taken by the Legionaries were recorded in a book.

Makdisi's (1986) remarks on the development of the diary keeping throughout the history is very interesting. In the western world, the oldest diary is an anonymous French journal named "Journal d'un bourgeois de Paris de 1405 à 1449". The oldest English diary is from 1442. The existence of previous diaries is unknown. In general, diaries with a higher sense of individualism and self-awareness are supposed to come along with Renaissance after the end of the Middle Ages. As a contrast to the western world, in the history of Islam, the diary keeping had developed earlier. In 
1072, diaries written by the Muslim intellectual Ibn 'Aqil were discovered.

There are many diary classifications. One of the largest classifications belongs to Hiemstra (2001). According to him, the diaries are classified into nine as;

1. Learning journals that reflects thoughts, feelings, personal opinions, and even hopes or fears during an educational experience;

2. Diaries in which individual feelings are expressed on specific days or time intervals;

3. Dream book or log in which dreams are recorded or interpreted for personal or psychological reasons;

4. Autobiographies, life stories and memoirs in which life stories and memoirs are written;

5. Spiritual journals that involve the recording of personal reactions to spiritual matters; professional diaries held by students to record their progress;

6. Professional journals that students keep to record their progress;

7. Interactive reading $\log$ that contain a series of responses to elements of any material being read;

8. Theory $\log$ that allow every student to learn to reflect critically on related terminology, theory, and knowledge;

9. Electronic journaling keeping in which any of these logs is fully or partially electronically distributed.

In the literature, the main type of diaries as a research topic is learning journals. According to Çelik (2006), multiple evaluation techniques such as performance evaluation, originality evaluation, keeping a diary, teacher observations, interviewing, holistic filing, problem-solving are used to reflect the meaning of the learners. Sá (2002) described that a classroom diary is a report written immediately after each class by a participating observer and contains a collection of qualitative data about the teaching-learning process. Tang (2002) suggests that keeping such diaries reflects the actual teaching and learning activities of the students, researching and expressing what they learn, linking and applying their learnings to their teaching and assessment practices.

There are many types of research regarding reflective or learning journals such as science and technology (Çavuş, Özden, 2014; Cengiz, Karataş, 2014), mathematics (Hensberry, Jacobbe, 2012; Atasoy, Atasoy, 2006); teacher's practice (Alterman, 1965; Ekiz, 2006; Numrich, 1996; Gömleksiz, Sinan, Demir, 2010; Koç, Y1ldız, 2012); teaching English as a foreign language (Barjesteh, Vaseghi, Gholami, 2011; Kır, 2012; Marefat, 2002); teaching Turkish to foreigners (Melanlığlu, Atalay, 2016); home studies (Güvenç, 2011); postgraduate (Tang, 2002); engineering (Wallin, Adawi, 2017); academic writing (Klimova, 2015). The use of the concepts of "reflective and learning logs" for a similar type of research in the literature can lead to a conceptual conflict. If it is thought that almost any kind of diary is a reflection of a person who keeps it, it may be more appropriate to name such diaries as the "learning diary" that represents the actual teaching process.

There are also studies of teacher diaries (Jeffrey, 2004; Mcdonough, 1994), a tool for teachers' personal and professional development. These diaries allow teachers to self-assess their teaching processes.

In the literature, there has not been any other research conducted other than the learning journals and teacher journals. Although the importance of other types of diaries kept daily on a regular basis in the development of writing skills cannot be denied, there is no research done on the role of diary keeping on the development of writing skills. For this reason, here in this study, the diaries kept for two months by Turkish language teacher candidates and their opinions about their diaries were examined to reveal their thoughts about the writing process and the writing skills improved by diary keeping to express themselves freely.

\section{Method}

This study is a qualitative study for examining the diaries kept by Turkish language teacher candidates and interviews done with some of them regarding these diaries as well as the topic of diary keeping.

According to Patton (2015), the qualitative researches are done with purposefully selected small samplings. The study group of this research is constituted by Turkish language teacher candidates who were studying in the third grade at Aksaray University. 26 of the 36 candidates surveyed were females and 10 were males. Participants were 22-23 years old. Also, semi-structured interviews were conducted with 17 randomly selected teacher candidates.

Methods such as observation, interviewing, and document examination can be used in qualitative researches. In this study, document review and interview methods were used. Participants were asked to keep their diaries daily for two months within the "Writing Education" lesson. The start date of the diaries was 04/04/2018 and the end date was 04/06/2018.

The document review method was used in the examination of the diaries. The analysis of the document review includes 
an analysis of written materials containing information about the targeted cases. According to the report of Yildirım and Şimşek (2011) and Forster (1995), the document review can be done in five major stages: 1) accessing the documents; 2) checking the originality; 3) understanding the documents; 4) analyzing the data; 5) using the data.

The diaries of the Turkish language teacher candidates were used in this research. A total of 36 diaries were collected, and 34 of them were worth to be analyzed, 2 of the diaries were out of scope because of inelaborate and careless spelling. All of the diaries were unique. A total of 2040 pages of diaries were read and analyzed. According to the codes, categories were developed, frequency values were used for digitizing the data and sample expressions were included to this article.

In qualitative research, document review can be a sole data collection method or can be used along with other data collection methods. In qualitative research when the document analysis used in conjunction with other data collection methods such as observation and interviewing, it will serve to the purpose of data triangulation and will increase the validity of the research (Yıldırım, Şimşek, 2011). For this purpose, a semi-structured interview was held with participants about the diaries one month after the diaries were collected and they were asked the following question: "You have experienced keeping a diary. What are your thoughts about keeping a diary?" Their answers were recorded, and 10-page long interview data were analyzed. Triangulation of qualitative data sources was made as was described by Patton (2014). This is a comparison and mutual control of the consistency of information obtained at different times and by different means within qualitative methods. There are many ways to perform this. In this study, the interviews were compared to the documents obtained in the interviews and other written evidence (diaries) that supported the interviewers' reports.

Content analyzing method and NVivo 11 Pro program was used in the analysis of the documents and interview data. To reduce the difficulties of qualitative data analysis, the qualitative data analysis process in the research was complied step by step. The qualitative data analysis processes that were described by Merriam (2013), Yıldırım and Şimşek (2011), Marshall and Rossman (2006) were examined, and a similar data analysis process was used in the analysis of the interview data. In this direction, the data were coded, the themes were described, and all the data were arranged according to codes and themes. Finally, all the findings were reported.

After the completion of the analysis, to ensure reliability in the study, the analysis was reperformed by both two other experts. According to the recurrence percentile formula (Reliability = Number of agreements / Number of agreements + disagreements) (Miles and Huberman, 1994) reliability of the diaries in the document analysis was found .93; and the reliability of the interview analysis was .95 . Afterward, the differences were discussed, and upon discussions, the differences were reduced to a minimum level. Furthermore, as Patton (2014) pointed out, consistency in the overall patterns of data obtained from different sources (diaries, interviews) or in reasonable explanations of data coming from separate sources can contribute considerably to the credibility of findings.

\section{Findings}

Here the findings of the diaries written by the Turkish language teacher candidates and the semi-structured interviews that were conducted with them will be presented.

\subsection{Diaries}

It is observed that the themes dealt with by the teacher candidates in their diaries were about education-teaching activities, life, feelings, thoughts, relatives, nature, important days, diary, problems, personal development, and writing skills. Among these, the themes which contain the expressions about keeping diary were separately grouped as about diary, problems, personal development, and writing skills. In the frequency table below, the first frequency value indicates how many people $(n)$ expressed the concept and the second value indicates the repetition frequency $(f)$. 
Table 1. The number of people and repetitive frequencies of expressions related to Education-Teaching Activities, Life, Feelings, Thoughts, Relatives, Nature and Important Days themes

\begin{tabular}{|c|c|}
\hline $\begin{array}{l}\text { Education } \\
\text { Teaching }\end{array}$ & $\begin{array}{l}\text { Examination (34)(396), Homework application (32)(48), Community service (5)(10), Reading } \\
\text { ooks (11)(33), Lessons (38)(341), TOMER visit (20)(20), Lesson processing (10)(32) }\end{array}$ \\
\hline Life & $\begin{array}{l}\text { Disease (28)(76), Meeting with friends (48)(184), Playing games (15)(42), Garden and field work } \\
(8)(21) \text {, Travel (28)(81), Sleep (12)(24), Watching movies/TV (37)(92), Listening to music } \\
(8)(15) \text {, Guesthouse (20)(90), About the dormitory }(8)(30) \text {, Book fair (7)(10), Festival (15)(28), } \\
\text { Trip (27)(73), Meals (36)(76), Shopping (20)(40), Working at a job (6)(42), Cleaning/tidying up } \\
(13)(29) \text {, Sports (Football, Basketball, Hiking, Biking) (16)(37) }\end{array}$ \\
\hline & Love (7)(15), Missing someone or something (25)(73), Sadness (34)(56), Happiness (28)(78), \\
\hline Feelings & $\begin{array}{l}\text { Tiredness }(20)(62), \text { Stress }(15)(21) \text {, Emotion intensity }(4)(10) \text {, Anger }(8)(16) \text {, Excitement (13)(20), } \\
\text { Hate (4)(6), Depression }(7)(13), \text { Anxiety }(24)(38) \text {, Loneliness }(5)(6) \text {, Unwillingness }(24)(56)\end{array}$ \\
\hline Thoughts & $\begin{array}{l}\text { On Language and Literature (24)(37), Politics (4)(4), People (22)(44), One's self (38)(59), City } \\
(9)(13), \text { Time (12)(16), Education (6)(8), Occupation (6)(6), Death (5)(7) }\end{array}$ \\
\hline & Family (18)(70), Mother (9)(29), Grandmother (3)(3), Brother (10)(19), Elder sister (6)(24), \\
\hline Relatives & $\begin{array}{l}\text { Nephew }(4)(11) \text {, Brother in law }(1)(1) \text {, Uncle }(1)(5) \text {, Father }(3)(5) \text {, Elder brother }(2)(7) \text {, Brother of } \\
\text { your mother }(1)(1) \text {, Uncle's wife }(1)(2) \text {, Wife's sister in law }(1)(1)\end{array}$ \\
\hline Nature & $\begin{array}{l}\text { Weather forecast (18)(52), Animal (5)(20), Days (8)(13), Love of nature (1)(1), Flower (1)(1), } \\
\text { Months (2)(2) Season (2)(3), Night (1)(2) }\end{array}$ \\
\hline Important Days & $\begin{array}{l}\text { Birthday (18)(36), Official Holidays (April 23, May 1, May 19) (15)(16), Engagement, Henna } \\
\text { night, Wedding (12)(24), Mother's day (5)(5), Anniversary of death (3)(3), Islamic religious days } \\
\text { (Fridays, Ramadan etc) (48)(184) }\end{array}$ \\
\hline
\end{tabular}

It is seen that the Turkish language teacher candidates mainly wrote about their educational activities and experiences in their diaries. Some participant statements regarding this theme are as in the following:

"I went to the school two hours before the exam hoping that maybe I can learn something new. But it was not as I expected, just the opposite happened, and I got confused. As the wise man says, hope is the poor man's meal. So I took my test hoping to get good results. The exam ruined this whole beautiful day." (2a)

"And I understood how wonderful it is to have chosen this profession and it is so beautiful that they call me teacher and the respect that they make me feel truly worths everything." (4a)

"We went to the place where my cousin would be circumcised. In our region, they serve a special dish on these days which is called Tirit." (7a)

"Oh, thank god that sleeping exists. It is the place where we flee from the fussiness of the world." (18a)

"I miss Adana. I understand that what connects a person to the places is related to what one finds there of oneself..." (6a)

"When the furniture was moved out of the room, it seemed as if the soul of the room left. There were no pictures or posters on the walls. Cabinets, racks were empty." (4a)

"I seem to have missed my childhood." (7a)

"It seems like I have to change somethings in my life, but I have no idea what I'm going to change. I am officially in depression, and I immediately have to add something new to my life." (4a)

"My siblings are my most valuable ones. Because I am close to them as a mother rather than as an elder sister." (3a)

"The day is over. One day it seems so short, in a vicious cycle that leaves us in. It is cruel to experience the same things over and over again." (6a) 
Table 2. The number of people (n) and repetitive frequencies (f) of expressions related to the Diary, Problems, Personal Development, Writing Skill themes

\begin{tabular}{|c|c|c|c|}
\hline Themes & Code & $n$ & $f$ \\
\hline \multirow{10}{*}{ Diary } & Addressing the diary & 5 & 10 \\
\hline & Talking to the diary & 2 & 2 \\
\hline & The fact that a diary cannot be written every day & 1 & 1 \\
\hline & Starting to love the diary & 1 & 1 \\
\hline & Diary as a burden at the beginning & 1 & 1 \\
\hline & Getting bored of keeping a diary & 1 & 1 \\
\hline & Love keeping a diary & 2 & 2 \\
\hline & Dislike keeping a diary & 2 & 2 \\
\hline & Missing the diary & 1 & 1 \\
\hline & Sharing the good things & 2 & 2 \\
\hline \multirow{5}{*}{ Problems } & Not being able to find anything to write & 4 & 6 \\
\hline & Having difficulties in writing & 3 & 3 \\
\hline & Having an ordinary life & 6 & 8 \\
\hline & Not being able to get very intimate & 1 & 1 \\
\hline & Not being able to pour out one's heart to the diary & 2 & 2 \\
\hline \multirow{7}{*}{$\begin{array}{l}\text { Personal } \\
\text { Development }\end{array}$} & Realizing that life has been wasted & 5 & 8 \\
\hline & The relaxation that comes with writing. & 3 & 4 \\
\hline & Feeling like writing is therapy. & 1 & 1 \\
\hline & The fact that the diary listens to the person who keeps it & 1 & 1 \\
\hline & Seeing the diary as a friend to whom one expresses thoughts & 1 & 1 \\
\hline & Putting one's life in order & 1 & 1 \\
\hline & Taking time for oneself & 1 & 1 \\
\hline \multirow{12}{*}{ Writing Skill } & Wishing to continue & 4 & 4 \\
\hline & Deciding to write a diary & 2 & 2 \\
\hline & Writing a poem & 3 & 3 \\
\hline & Help that comes from writing skills & 1 & 1 \\
\hline & Getting used to keeping a diary & 3 & 3 \\
\hline & Not being able to get used to keeping a diary & 2 & 2 \\
\hline & Earning a good habit & 1 & 1 \\
\hline & Beginning to have fun while writing & 1 & 1 \\
\hline & Getting used to writing and continuing & 1 & 1 \\
\hline & Being happy to write on a regular basis & 5 & 6 \\
\hline & The desire to save the written things & 1 & 1 \\
\hline & The desire to pay attention while writing & 1 & 1 \\
\hline
\end{tabular}

It is observed that the Turkish language teacher candidates talk to, personalize, love or dislike their diaries and demand things from the diaries they keep. Some of the students have addressed the diary in various ways as in the following: $M y$ dear diary (1a), My dear confidant (9a), We will all gonna solve them up mate (9a), Greetings the black covered (10a), From now on you will be my confidant, my friend, and my partner (14a), Pray for me (19a).

Some expressions of the participant on the "Diary" theme are:

"I started to love you. Let's meet every day." (9a) 
"The thing which is called diary cannot be kept every day. Because the people do not experience important things every day of their lives." (4a)

"My dear thoughts! I say my dear thoughts because rather than a diary I see you as a friend of mine to whom I can express my feelings." (11a)

Some of the expressions of the participants on the "Problems" theme are as in the following:

"My life has passed just with tests, homework and that is it. Goodbye diary, I told you parts of my life. Believe me; I do not live more than what I have written on you." (1a)

"Believe me sometimes I have no idea what to write to you. I spend such ordinary days that I do not want to keep writing the same things." (11a)

"I understood that I could not write regularly. I do not know why, but I cannot write. I am having trouble even writing these lines right now." (11a)

"I will self-criticize myself when the subject comes to writing. I do not trust myself in writing. I hated to share the things that I wrote with people. Because what I wrote was constantly criticized and modified. Because of that, I hated writing. It's childish. But if I had the current mind, I would write more. I could write one more article for every unfavorable article that I had written previously, maybe by this way I could improve myself." (15a)

The student who wrote the phrase "I cannot express myself to you, dear diary." after two weeks wrote, "Hey diary listen, I think we are well united with you." (18a)

Some participants' expressions on the "Personal Development" theme are as in the following:

"I have not kept a diary regularly until this time. It feels good. You unburden myself, and I feel relieved. Very well, it feels like therapy to me. I want to continue doing this." (3a)

"Today I understand that when I keep this diary, I start to notice how empty and boring my life is. It is the biggest benefit of keeping a diary. I have been living in emptiness. I have not even realized it before." (12a)

"I understand as I write to you, I am living a life as meaningless as the sentences I write to you." (18a)

Some of the expressions of the participants regarding the "Writing Skill" theme are as in the following:

A participant stated that he was used to writing daily after a month of starting to keep the diary and he used the following expression on the last day: "Here we came to the end of my diary. But I'm used to it. Some of the other friends have neglected to write. They have neglected themselves. The diary is about taking time for yourself. How generous it can be when someone does not take time for himself and take time for someone else. I will continue to keep a diary. I took that decision." (6a)

"I checked my previous handwritings; they were pretty ugly. I need to pay more attention to this." (34a)

"I tried to tell you about my emotions, thoughts, and liveliness during the two months I spent with you. I do not know how successful I was on it, but I enjoyed very much this period of time. Yes, I kept the diary as a homework, but internally, I filled the lines by living the happiness of keeping it daily. Hopefully, we will meet again someday." (12a)

"I started to keep a diary as homework. But now I feel sorry. The first times seemed like a burden. Then I got used to it." (16a)

"At first I was writing very unwillingly, and I got used to writing it later on. I liked this diary writing task." (20a).

"I thank you for making me write regularly. It was a good experience for me. Goodbye." (24a)

The student who started his diary with "I think I do not like to keep a diary. It is better to share it with people rather than sharing it with papers.", after two months on the last day of his diary stated that, "I have lived and shared a lot with you. It has been two months. Maybe I will continue writing. I started to enjoy writing it day by day." (33a)

Some students have quoted concise words and some quotations from books in their diaries:

"Let's thank the people who make us happy. They are lovely gardeners who bloom our souls." (Marcel Proust)

"If you want to fly, leave everything that pulls you down." (Tony Morrison)

"Think before you talk: Is it necessary? Does it have compassion? Is it worth to break the silence?" (Lao Tzu)(17a)

Also, four students have noted emoji gifs like a smiling face, upset face, and heart (2a, 15a, 20a, 26a). One participant filled up his diary with words, pictures, and figures quoted from poets and writers (17a). Three students also dried flowers within their diaries pages (3a, 12a, 15a). 


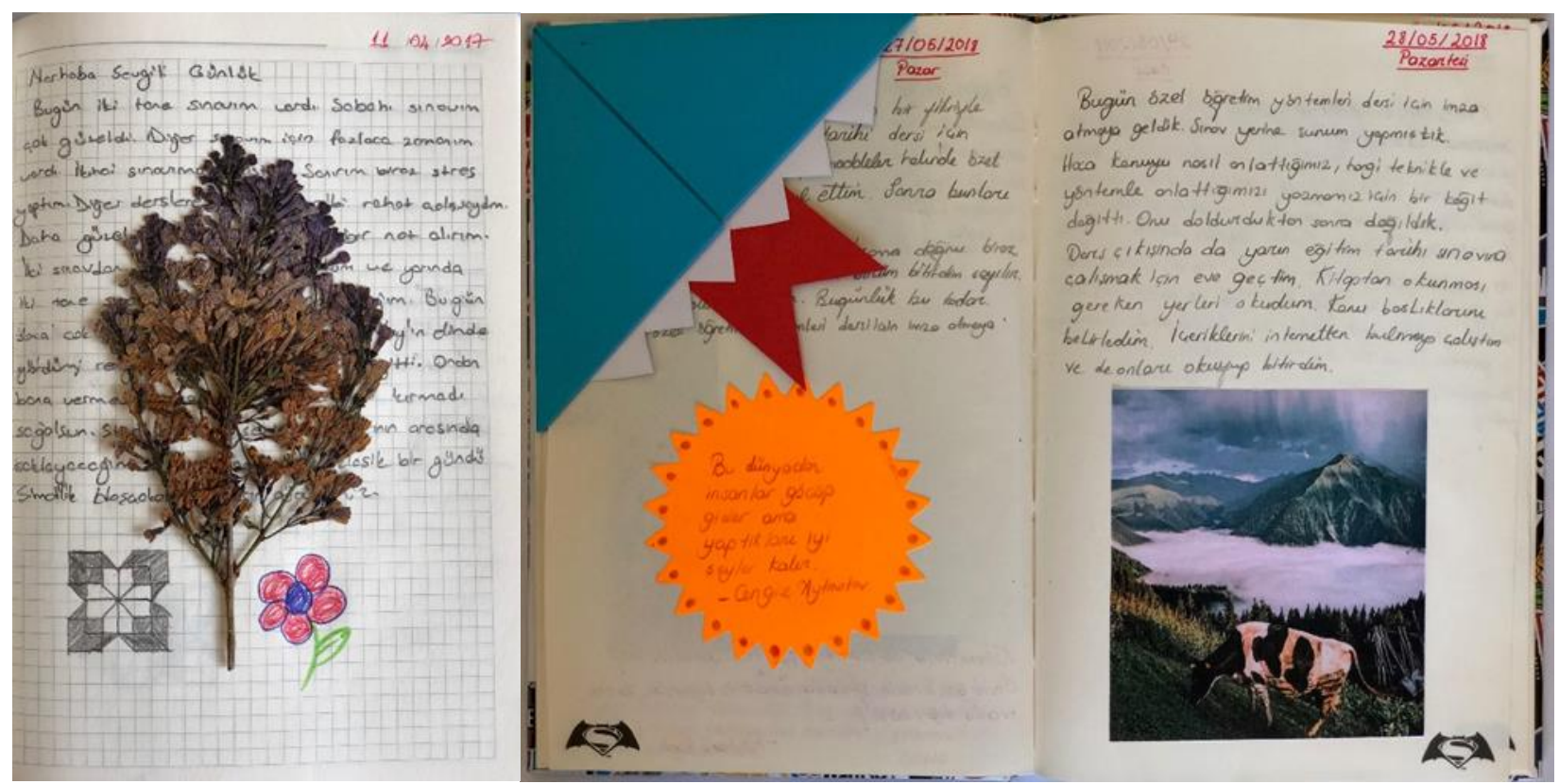

Figure 1. Examples from the diaries

\subsection{Interviews}

The codes that were created regarding the interviews were grouped into diary, problems, personal development and writing skill themes.

Table 3. Codes and frequency values for the Diary theme

\begin{tabular}{ll}
\hline Code & $f$ \\
\hline Being aware of self-importance & 1 \\
Sharing a lot of things with a diary that cannot be told to someone & 1 \\
else & 1 \\
Be a port of refuge & 1 \\
Sharing a person's relationship in a comfortable and reliable & \\
environment & 1 \\
Making memories permanent & 1 \\
Being a type of writing that busy people have to write & 2 \\
Writing like a conversation with a friend & 1 \\
Being a perfect thing & 3 \\
Observing the past experiences & 1 \\
Being a friend that keeps secrets & 1 \\
Being able to tell everything & 1 \\
Putting a person's past in chronological order & \\
\hline
\end{tabular}

Some expressions of the participants on the diary keeping are as in the following:

"Passing 3-4 days in the same commonness made me stop, think and talk to myself. Hey, what am I doing? But afterward, I realized that keeping diary was not a transfer of what we did purely in daily life, it should not be... For example, you have spent an ordinary, inactive day at home, but then you have started to think about a topic, and there is nobody around to share it. At that time diary becomes your closest friend with whom you can share these thoughts and ideas that fly around your mind." (6b)

"Keeping a diary is to write about the things that happen that you are afraid and ashamed to tell. Diary keeping is like writing as if you have a conversation with a close friend." (9b)

"I am not a type of person who could share his problems comfortably by words or by showing them with my behavior 
when I am bored. Because of this, the diary has become for me as a friend who will never tell my secrets to anybody." (10b)

"While keeping a diary, I realized that many forgotten memories have happened in our lives. I understand how enjoyable it is to keep a diary when I read the diary." (11b)

Table 4. Codes and frequency values for the Problems theme

\begin{tabular}{ll}
\hline Code & $f$ \\
\hline Finding diary keeping insecure & 1 \\
Inability to fully transfer the feelings and thoughts & 1 \\
Being a little unwilling in the beginning & 1 \\
Not being able to find anything to write & 2 \\
Forgetting the things that happen during the day & 1 \\
Being bored of writing similar things & 1 \\
Not being able to write feelings and thoughts sincerely since the & 3 \\
researchers will read them & \\
Not being able to find a topic to write about & 3 \\
Having difficulty in expressing oneself & 2 \\
Not having anything worth writing in life & 3 \\
Feeling bored with writing a diary & 1 \\
The fear that someone will find and read the diary & 2 \\
Having ordinary days & 3 \\
Unwillingness to express feelings & 1 \\
\hline
\end{tabular}

Some of the expressions of the participants' problems in diary writing are as in the following:

"I have had the experience of keeping a diary in the past. I have always written a couple of pages and then threw it away. My thoughts have never changed, in fact, I always had a fear of the fact that someone is going to read my private things. I always found it insecure." (1b)

"I usually did not find anything worth to write during the day. I was very tired of the necessity to write every day without finding anything to write. At that point, the diary reminded me that I should put my life in order." (5b)

"There were certain issues that I transferred to the diary. In my personal life, I am a person who does not leave the house in general, spending most of the day at home, so the things to be written were limited. For this reason, it is often difficult to find a topic to write in the diary." (7b)

"After keeping a diary, I realized that I had difficulties in writing. I could not even write what I needed to write that day. Keeping a diary contributed to my writing, now it is better and more organized." (9b)

"The diary keeping is completely uneasy for me. I do not know what to write, and writing day by day makes me even more confused. I do not live different things every day. Every day there are no different feelings and thoughts." (16b) 
Table 5. Codes and frequency values for the Personal Development theme

\begin{tabular}{ll}
\hline Code & $f$ \\
\hline Relaxation & 3 \\
Not being suitable for the character of emotional people & 1 \\
Being like a therapy & 2 \\
Escaping from being lost in the emptiness & 1 \\
Spending time for oneself & 1 \\
Listening to the inner voice & 1 \\
Being like a mirror & 1 \\
Understanding yourself and making future adjustments & 5 \\
Being a pleasurable inner discovery & 1 \\
Ensuring to be more open in human relations & 1 \\
Developing a solid posture against life & 1 \\
Making others feel that you have an idea & 1 \\
Ensuring that the person better expresses oneself & 1 \\
\hline
\end{tabular}

Some of the expressions of the participants regarding the importance of diary keeping on the personal development are as in the following:

"There have been many times that I told to myself I wish I had started writing earlier. Writing every day about my days made me express myself better. It also contributed to balancing the reactions I gave or my responses to certain events and situations. I realized that I needed to be more open in my relationships. When I checked the things I wrote, I observed my difficulties in writing were diminishing. The diary keeping often helped me write and reminded me things. It makes you feel that you have an idea to express yourself, to develop a solid posture against your life." (5b)

"The most simple way to explain what keeping a diary is about is to spend time with yourself. An attempt to listen to your inner voice, or evaluating the things that are done and are planned to do. These all manifest simply in a diary. It almost makes you say, I have lived today, and I have things to say." (6b)

"When I keep a diary, I always told myself that; You always live the same things and do not want to write. The diary becomes a mirror to me. I started to write; when I am done, I figured out that my life was empty." (12b)

"Knowing our reactions to what we are currently experiencing always helps us to understand ourselves better, and we can improve in the future. It can even make us leave the mistakes that we do. Also keeping a diary means a person's chronological history." (14b)

"It was a nice and fun experience. I felt like I was having a conversation with a friend while I was writing my diary. When I finished writing at the end of the day, I noticed that there was a slight smile on my face and that it made me feel so relieved." (15b)

"Keeping a diary more regularly and planned led me one step forward. Another contribution of diary keeping is to make me psychologically more stable and happier." (17b) 
Table 6. Codes and frequency values for the Writing Skill theme

\begin{tabular}{ll}
\hline Code & $f$ \\
\hline Getting more enjoyable as the time passes & 1 \\
Increase in the curiosity on writing & 1 \\
Learning how to get happy by writing & 2 \\
Requiring willingness and constancy & 1 \\
Being a nice and fun experience & 1 \\
Being an important contribution to acquire writing habits & 1 \\
Realizing the improvement in writing skills & 1 \\
Observing the problems due to lack of writing get better & 1 \\
Realizing the difficulties while writing & 1 \\
Improving writing skills in a better and organized way & 1 \\
Realizing that one can express himself more easily in writing & 1 \\
Getting used to writing & 1 \\
Realizing the inadequacies in writing a subject & 2 \\
Recognizing that one's vocabulary is insufficient & 1 \\
Being able to write in a specific style & 1 \\
Providing practice in using punctuation marks & 1 \\
\hline
\end{tabular}

Some expressions of participant's about writing skills are as in the following:

"Although I started to write the diary with not having fun at all, as the time passed it began to get better and more enjoyable. It started to be a pleasurable process. My curiosity to write was an action that increased my admiration. I learned how to be happy by writing and unburden myself of somethings by keeping the diary. It is an enjoyable domestic journey for me to keep a diary." (2b)

"I realized that my writing skills have improved by keeping a diary. There was a clear distinction between the diary I wrote on May 4 and the diary I wrote on June 4." (3b)

"I will continue to keep a diary. And this situation made me get used to writing on various topics." (6b)

"After my diary writing, I realized that I am a good speaker. But I can express myself more easily when writing." (10b)

"I continued to write my diary. Sometimes I wrote a poem, a question or a thought that confuses my mind. I did not hesitate writing the beautiful memories I had that day." (11b)

"Being able to achieve planned and daily diary keeping showed me my difficulties in writing. Because when I read what I wrote, I realized that I could not fully express my mind. I realized that I made mistakes in the conjunctions between the sentences and that my vocabulary was narrow." (15b)

"I can say that keeping diary improved my writing skills within a specific composition and helped to practice punctuation marks that I had difficulties. It was an enjoyable task for me when I wrote my diary to add a proverb or a drawing that was appropriate for the day instead of just writing a simple text." (17b)

\section{Conclusion and Discussion}

It is seen that the topics covered by the Turkish language teacher candidates in their diaries are about their education-teaching activities, experiences, feelings, thoughts, relatives, nature, important days, diary writing, problems, personal development, and writing skills. Participants mainly wrote about educational activities and daily life while keeping their diary. The style of addressing their diaries, the way they talked with it, missing the diary are the signs that they have imposed various meanings to their diaries. The diary keeping made the participants realize it has an essential role in the personal growth in many ways. By diary keeping some of the participants realized that they were wasting their days, some of them felt relaxed when writing, some felt it is therapy or a friend to whom they express their thoughts, help them put their lives in order. As Yildiz and colleagues (2008) have described, the benefits of writing upon psychology, social behaviors, pedagogy, and language development cannot be denied. A person can overcome his psychological problems by writing and find peace of mind in expressing himself/herself.

The fact that the participants decided to continue diary keeping and to write it daily, getting used to writing it and feel 
happy for that and continue to write in various genres is an indication of how important effects it has to keep a diary on writing education.

The themes that emerged in the interviews regarding the diaries kept by the participants were related to the daily problems, personal development, and writing skills. Participants described that diary keeping has been meaningful as they shared a lot of things that cannot be told to others, sharing a connection with oneself in a comfortable and reliable environment, chatting with it as a friend, writing a secret onto it, diary as a secret friend, reminder of the past, putting the person's past into a chronological order, and so on. As the participants have noted into their diaries, the most important problems they have experienced were the inability to find something new to write because their days were very ordinary and the fear of being read by others. Similar to what Johnson (2006) has described, in this research diaries also made it possible for the person to self-observe and improve their relationship with themselves. Under the personal development theme, just as in the diary expressions such as relieving a person, being like a therapist, knowing oneself and making corrections for the future, developing a stable posture, making feel like one have an idea, and making someone better express themselves were used. According to Hiemstra (2001), diary benefits include personal development, intuition and self-expression, problem-solving, stress reduction, health benefits, reflection, and critical thinking.

The fact that the diary-keeping has become more enjoyable with time, the increase in the curiosity for writing, learning how to be happy by writing, writing like a nice and fun experience, being an important contribution to writing habit, becoming aware of the development of their writing skills with diary keeping, its positive effects on writing in a certain composition style and the punctuation marks, etc. are all indicators of the importance of diary keeping. Barjesteh, Vaseghi, Gholami (2011) pointed out that keeping a learning diary can affect students' that are learning English as a foreign language affects their attitudes significantly toward writing. Melanlığlu and Atalay (2016) found that keeping a diary of the Turkish foreign language learners has significant effects for the self-efficacy. This research can be interpreted as the participating Turkish language teacher candidates got accustomed to writing a diary as they expressed that they have developed a positive attitude towards writing and diary keeping increased their self-efficacy. As Wallace (1977) described, a certain amount of writing every day affect the writings of the writers, and the ability of self-denomination develops at this point. It can be said that the participants became aware of their lives and had been accustomed to day-to-day writing and keeping the diary have improved their self-regulation skills.

This research reveals that individuals who routinely keep track of their lives by diary writing begin to question their lives and try to organize their life and that diary keeping, which helps to write regularly, has an important role in the development of their writing skills.

\section{References}

Alterman, A. R. (1965). Using student diaries to develop an evaluative instrument for teacher education programs. The Journal of Educational Research, 58(8), 369-372. https://doi.org/10.1080/00220671.1965.10883247

Atasoy, E., \& Atasoy, Ş. (2006). Determination of the effects of different writing activities on thought and behavior of 6th grade students. Journal of Hasan Ali Yücel Education Faculty, 2, 1-18.

Bangert, D. R. L., Hurley, M. M., \& Wilkinson, B. (2004). The effects of school-based writing-to-learn interventions on academic achievement: meta-analysis. Review of Educational Resarch, 74(1), 29-58. https://doi.org/10.3102/00346543074001029

Barjesteh, H., Vaseghi, R., \& Gholami, R. (2011). The effect of diary writing on Efl College students' writing improvement and attitudes. International Conference on Language, Literature and Linguistics, 26, 143-147, Singapore.

Cengiz, C., \& Karataş, F. Ö. (2014). Developing reflective thinking: Effects of keeping reflective journals with pre-service science teachers. Journal of Research in Education and Teaching, 3(4), 120-129.

Çavuş, E., \& Özden, M. (2014). Primary school students' views about use of science journal in science and technology course. Adlyaman University Journal of Educational Sciences, 2(1), 34-48.

Çelik, F. (2006). Targets in Turkish education system new directions in the targeting. Journal of Burdur Education Faculty, 6(11), 1-15.

Ekiz, D. (2006). Self-observation and peer-observation: Reflective diaries of primary student-teachers. Elementary Education Online, 5(1), 45-57.

Forster, N. (1995). The analysis of company documentation. Catherine Cassell, Gillian Symon (Eds.), Qualitative methods in organizational research: A practical guide in. London: Sage.

Gömleksiz, M. N., Sinan, A. T., \& Demir, S. (2010). An assessment of effectiveness of writing leaaning domain in 
elementary school Turkish Language Education Curriculum. Turkish Studies, 5(4), 1135-1173.

Güvenç, H. (2011). Effects of study diaries on sixth graders self-regulated learning. Hacettepe University Journal of Education, 41, 206-218.

Hensberry, K. K. R., \& Jacobbe, T. (2012). The effects of Polya's heuritic and diary writing on children's problem solving. Mathematics Education Research Journal, 24, 59-85. https://doi.org/10.1007/s13394-012-0034-7

Hiemstra, R. (2001). Uses and benefits of journal writing. New Directions For Adult And Continuing Education, 90, 19-26. https://doi.org/10.1002/ace.17

Jeffrey, D. (2004). A teacher diary experience. Asian EFL Journal, 6(2), 1-19.

Johnson, P. (2006). Habermas: Rescuing the public sphere. London: Routledge. https://doi.org/10.4324/9780203020166

Kır, E. (2012). Diary keeping in English lessons. e-Journal of New World Sciences Academy, 7(4), 1082-1094.

Klimova, B. (2015). Diary writing as a tool for students' self-reflection and teacher's feedback in the course of Academic Writing. Procedia-Social and Behavioral Sciences, 197, 549-553. https://doi.org/10.1016/j.sbspro.2015.07.189

Koç, C., \& Yıldız, H. (2012). The reflectors of teaching experiences: Diaries. Education and Science, 37(164), $223-236$.

Makdisi, G. (1986). The diary in Islamic historiography: Some notes. History and Theory, 25(2), 173-185. https://doi.org/10.2307/2505304

Marefat, F. (2002). The impact of diary analysis on teaching/learning writing. Relc Journal, 33(1), 101-121. https://doi.org/10.1177/003368820203300106

Marshall, C., \& Rossman, G. B. (2006). Designing qualitative research. London: Sage Publications.

Mcdonough, J. (1994). A teacher looks at teachers' diaries. ELT Journal, 48(1), 57-65. https://doi.org/10.1093/elt/48.1.57

Melanlığlu, D., \& Atalay, T. D. (2016). The relation between reflective diary use and writing self-efficacy: The case of foreigners who learn Turkish as a foreign language. Mustafa Kemal University Journal of Graduate School of Social Sciences, 13(35), 56-76.

Merriam, S. B. (2013). Qualitative research. USA: Wiley.

Miles, M. B., \& Huberman, A. M. (1994). Qualitative data analysis: An expanded sourcebook. London: Sage.

Numrich, C. (1996). On becoming a language teacher: Insights from diary studies. Tesol Quarterly, 30(1), $131-151$. https://doi.org/10.2307/3587610

Patton, M. Q. (2015). Qualitative research and evaluation methods. USA: Sage.

Sá, J. (2002). Diary writing: an interpretative research method of teaching and learning. Educational Research and Evaluation, 8(2), 149-168. https://doi.org/10.1076/edre.8.2.149.3858

Tang, C. (2002). Reflective diaries as a means of facilitating and assessing reflection. In Quality conversations: Proceedings of the 29th HERDSA Annual Conference Perth, 7-10.

Wallace, I. (1977). Self-control techniques of famous novelists. Journal of Applied Behavior Analysis, 10, $515-525$. https://doi.org/10.1901/jaba.1977.10-515

Wallin, P., \& Adawi, T. (2017). The reflective diary as a method for the formative assessment of self-regulated learning. European Journal of Engineering Education, 43(4), 507-521. https://doi.org/10.1080/03043797.2017.1290585

Willard, B. (1972). I: An anthology of diarists. UK: Chatto \& Windus.

Yıldırım, A., \& Şimşek, H. (2011). Qualitative research methods in the social sciences. Ankara: Seçkin.

Yıldız, C., Okur, A., Ar1, G., \& Y1lmaz, Y. (2008). Teaching Turkish from theory to practice according to the new curriculum. İstanbul: Pegem.

\section{Copyrights}

Copyright for this article is retained by the author(s), with first publication rights granted to the journal.

This is an open-access article distributed under the terms and conditions of the Creative Commons Attribution license which permits unrestricted use, distribution, and reproduction in any medium, provided the original work is properly cited. 